\title{
The Protective Role of Self-Efficacy for Resilience in the COVID-19 Period
}

\section{Andrea Kövesdi*, Krisztina Törő, Éva Hadházi, Szabolcs Takács, Sándor Rózsa, Gábor Csikós and Rita F Földi}

Resilient Development Positive Research Group, Károli Gáspár Református

University, Institute of Psychology, Budapest, Hungary

*Corresponding Author: Andrea Kövesdi, Resilient Development Positive

Research Group, Károli Gáspár Református University, Institute of Psychology,

Budapest, Hungary.
Received: September 26, 2020

Published: October 28, 2020

(C) All rights are reserved by Andrea Kövesdi., et al.

\section{Abstract}

The aim of our research group is to examine the protection of mental health during a pandemic. In our April 2020 study, we analyzed the association between stress, health anxiety and self-efficacy in terms of resilience. The study included 684 persons, arranged by parents and their children. Women are overrepresented in the sample. Based on the results, we can say that parental health anxiety and perceived stress reduce resilience. And self-efficacy is a protective factor for both parental and child resilience.

Keywords: Stress; Health Anxiety; Self-Efficacy; Resilience

\section{Introduction}

Pandemic periods are significantly stressed by the many unexpected changes, losses, and uncertainties that kick people out of their normal rhythm of life. Defending against a viral infection is a fight against an invisible attacker at all times. According to János Selye (1950), every unknown, unexpected life situation triggers a non-specific response, a vegetative stress reaction. During a pandemic, by definition, stress is clearly a long-lasting stress experienced by a people en masse. Thus, during a pandemic, in addition to vulnerable factors, personality protective factors such as resilience increase.

In maintaining mental health, personality protective factors provide protection against increased negative effects and associated stress. Therefore, we focused on resilience and the factors influencing it. Resilience helps a person in a stressful life situation, restoring spiritual, psychic and somatic balance [1]. The authors consider it likely that competent functioning maintained under stress may indicate resilience [2].
Resilience is a personality trait that is closely related to adaptability; among others, it is characterized by positive management of change, positive self-image and self-effective behavior [3]. Resilient individuals are able to store and positively use stress-induced stress [4]. Resilient operation is a complex adaptive ability that is constantly changing depending on age, life situation and external factors.

Some research has associated low educational attainment with low resilience in women during the COVID period (Kavcic, Avsec, Kocjan, 2020). Children with special needs and their mothers have been studied by Turkish researchers, and their results show that maternal self-efficacy and resilience go hand in hand (Kumas, Sümer, 2020).

Ability "to do" is clearly described by other authors as protection against the negative effects of a pandemic period (Barton., et al. 2020). American research has shown that individuals who moved out of their homes in the first wave of a pandemic moved regularly and maintained their human relationships within a given framework with higher resilience values (Killgore., et al. 2020). 


\section{Objective of the Study}

Our study objective was to provide stress responses of parents and their children during the first COVID-19 wave and their effect on resilience. We raise the question of how individuals who show higher resilience at the time of COVID-19 differ from their peers. In formulating our research objective, we relied on our practical experience (Kövesdi, 2018, 2019) and the international literature. We claim: 1) the resilience value of parents is higher than that of children. 2) Resilience shows a positive association with self-efficacy and a negative one with health anxiety and perceived stress. 3) Children experience less stress than their parents. 4) Perceived stress is higher among women compared to men. 5) Perceived stress and health anxiety reduce resilience. 6) Last but not least, parental self-efficacy influences child resilience.

\section{Presentation and method of the test sample}

According to the study design, parents and their children completed the questionnaire package. Random sampling was performed by the snowball method on an online interface. Women (75.73\%) were over-represented in the sample compared to men. In terms of national coverage of the sample, $23 \%$ of respondents in the capital, $58 \%$ of respondents came from rural towns and 19\% from villages. The total study sample included in the analysis was 648 individuals.

\begin{tabular}{|l|c|c|c|}
\hline & Age $/ \mathbf{M}$ & SD & N = 648 \\
\hline Fathers & 47.16 & 4.282 & 32 \\
\hline Mothers & 43.70 & 5.047 & 310 \\
\hline Boys & 14.07 & 2.211 & 134 \\
\hline Girls & 14.33 & 2.213 & 208 \\
\hline
\end{tabular}

Psychometric devices included in the study:

- CD-RISK 10-item resilience questionnaire [5],

- $\quad$ Perceived stress scale [6,7],

- $\quad$ Bandura self-efficacy questionnaire [8],

- $\quad$ Short health anxiety inventory $[9,10]$.

\section{Results}

The table 1 accurately depicts the ratio of parent-child pairs completing the questionnaires, clearly showing the shift of the sample toward the female gender, and that a total of 32 paternal completions have been analyzed. Thus, data on fathers can only be interpreted at the trend level. The graph 1 and 2 show the distribution of resilience in the sample.

\begin{tabular}{|l|c|c|c|}
\hline & Boy & Girl & Total \\
\hline Father & 14 & 18 & 32 \\
\hline Mother & 120 & 190 & 310 \\
\hline Total & 134 & 208 & 342 \\
\hline
\end{tabular}

Table 1: Test sample.

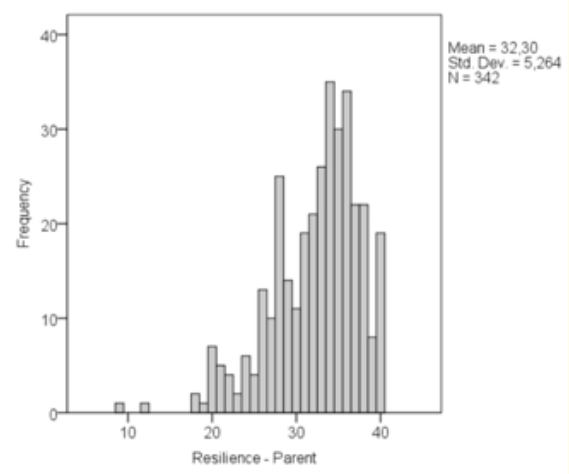

Graph 1: Parent.

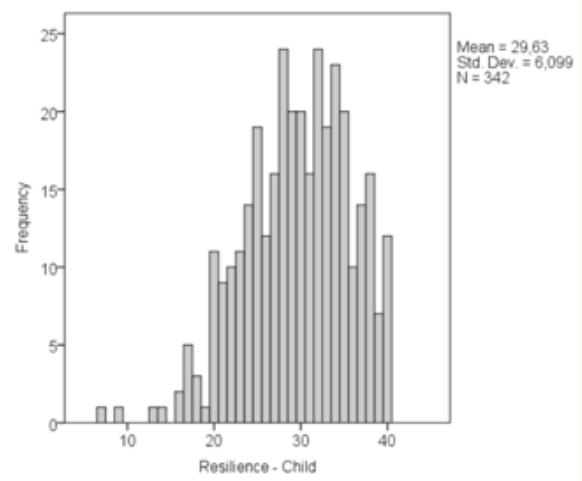

Graph 2: Child.

Resilience scores are in the mean range in both the parent and child groups. The mean value of parental resilience is higher (32.30) compared to the mean value of resilience of children (29.63). The first hypothesis was fulfilled (Figure 1).

The highest perceived stress in the sample is characteristic of girls, followed by boys, then mothers, and finally fathers. The parental mean value and the child mean value differ significantly, however, the significant measured difference is due to the high score of the daughters. The hypothesis was partially fulfilled, the average value of the perceived stress of the daughters is the highest! (Figure 2). 


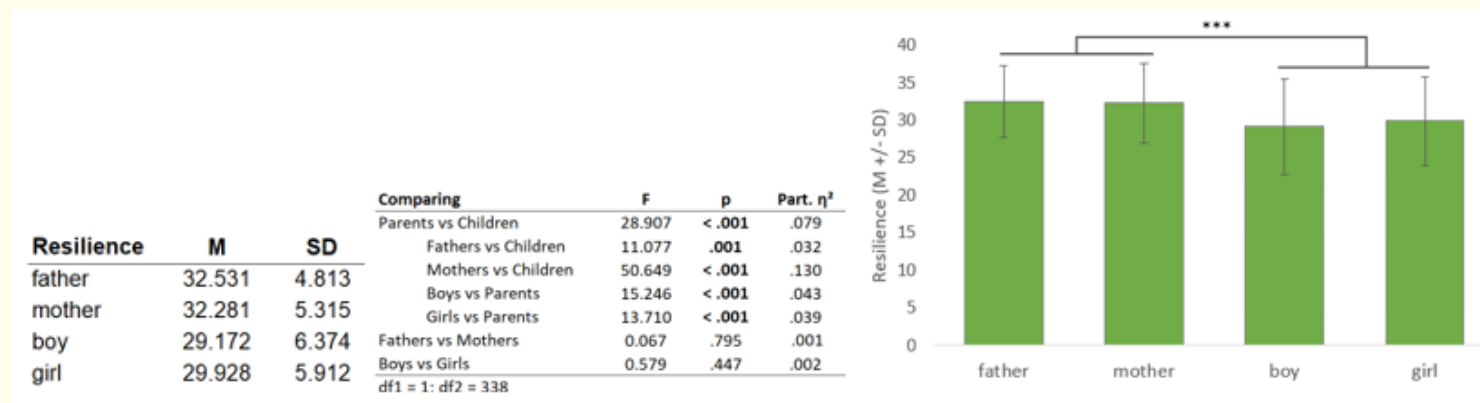

Figure 1: Resilience average.
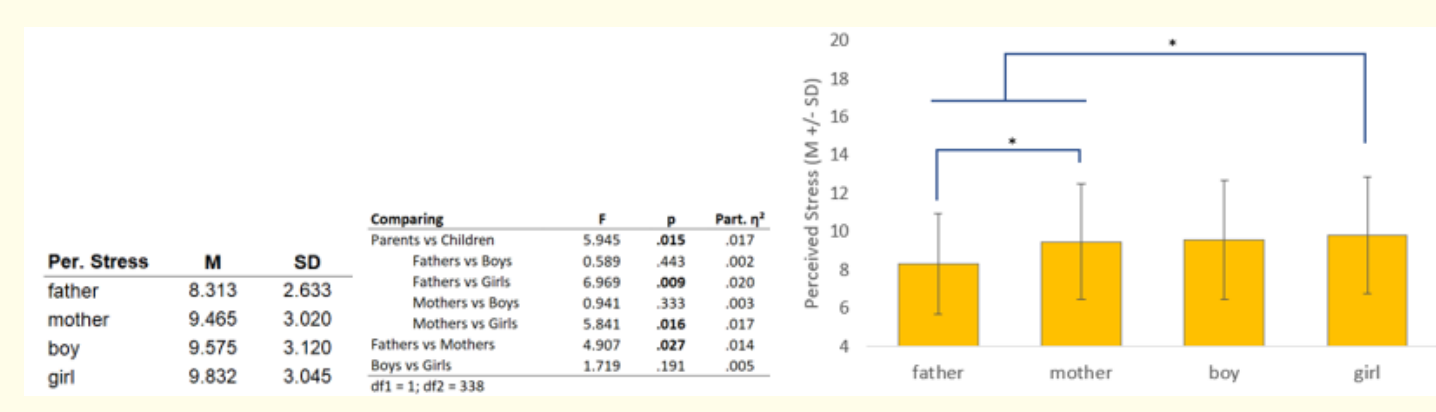

Figure 2: Perceived stress.

Parental health anxiety is higher compared to children, where mothers' health anxiety is significantly higher. We demonstrated a positive association of parental resilience with parental self-efficacy. In children, we also found this result at the trend level. Parental resilience shows a negative association with health anxiety and perceived stress (Figure 3).

\section{Presentation of mediating effects}

Mediating effects were analyzed and in the parental sample, we demonstrated that health anxiety exerts its effect on resilience in part through perceived stress. In addition to the indirect effect, health anxiety also has a direct effect on resilience, reducing it (Figure 4).

\begin{tabular}{lcc} 
Health Anx. & M & SD \\
\hline father & 10.188 & 2.221 \\
mother & 10.274 & 2.601 \\
boy & 9.097 & 2.120 \\
girl & 9.880 & 2.699
\end{tabular}

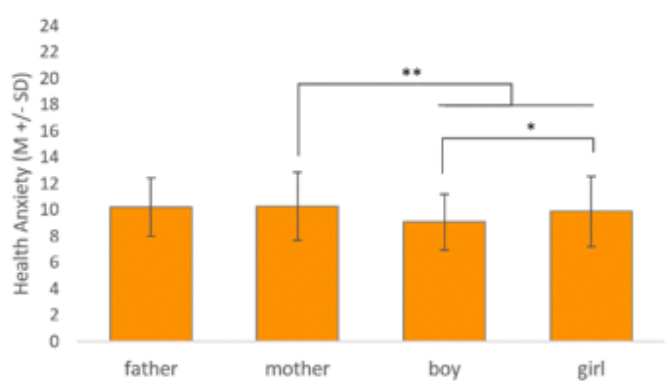

Figure 3: Health anxiety. 


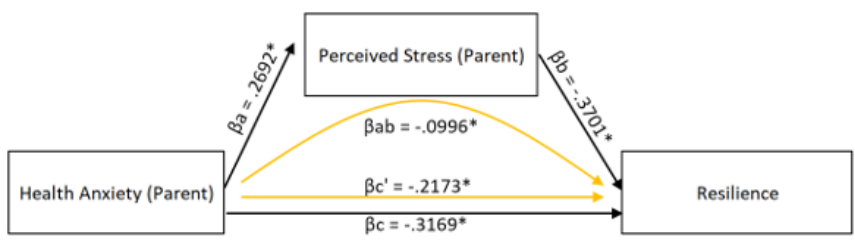

Figure 4: Mediating effects.

\section{Presentation of moderating effect}

After discussing the role of mediation found in the sample, we now examine the moderating effect of self-efficacy. It protects resilience against the resilience-reducing effect of parental perceived stress and health anxiety (Figure 5). Self-efficacy is a protective factor for resilience! It reduces the resilience-reducing effect of health anxiety and perceived stress.

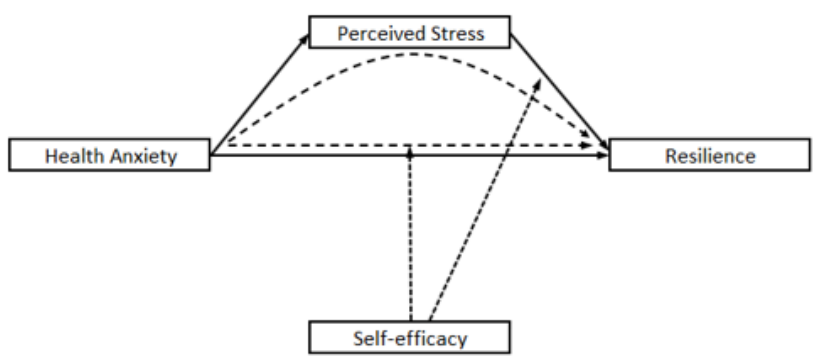

Figure 5: Moderating effect.

We found a mediating effect of perceived stress in children between health anxiety and resilience, however, pediatric self-efficacy does not moderate it. Parental self-efficacy moderates the effect of perceived stress on resilience in children. The sixth hypothesis was confirmed.

It can be concluded that parental self-efficacy is a protective factor against the resilience-reducing effect of perceived stress in children (Figure 6). That is, parental self-efficacy in both parents and children is a protective factor against the resilience-reducing effect of stress.

Four of the test hypotheses were confirmed $(1,2,5,6)$. Hypothesis 3. was discarded because the mean value of perceived stress in children is higher. Hypothesis 4 was partially confirmed because the level of perceived stress in daughters is the highest.
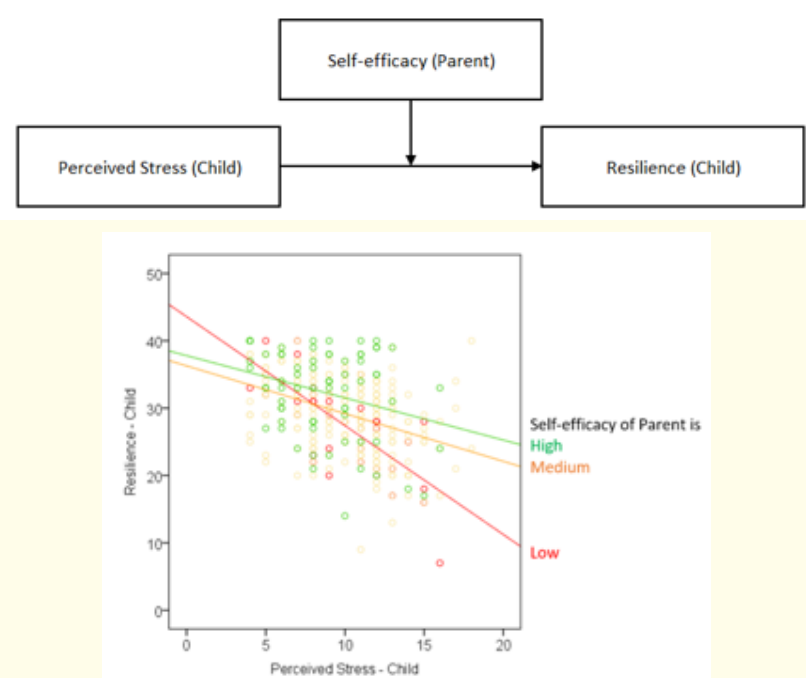

Figure 6: Protective factor.

\section{Discussion and Conclusion}

Based on our results, it can be concluded that the average resilience score of parents is higher than that of children, however, the average score of both groups falls in the average zone. Our results differ from the Slovak study data (Kavcic, Avsec, Kocjan, 2020), where a below-average score was measured during COVID-19.

Girls experience the highest stress in the first wave of a pandemic. However, the perception of high stress does not go hand in hand with a lower resilience value than would be expected. Further studies are needed to explain the result.

Self-efficacy is a protective factor against the resilience-reducing effect of stress and health anxiety among the parent. That is, supporting parental personal self-effective solutions is important for resilient responses. In the second wave of the pandemic, special attention must be paid to self-effective options and solutions (!) in addition to the limitations. Our results correlate with the results of several American and Turkish studies in the first wave of COVID-19, where "doing" and self-effective behavior were found to be factors supporting resilience (Barton., et al. 2020; Killgore., et al. 2020, Kumas, Sümer, 2020).

Pediatric self-efficacy does not affect the resilience-reducing effect of perceived stress. However, parental self-efficacy is a protective factor against the resilience-reducing effect of perceived stress in children. 
Parental self-efficacy is a protective factor for both parental and child resilience during a pandemic! A parent's self-effective solution is organized based on personal, creative ideas, drawing from their own resources the ammunition needed for execution. Based on our results, supporting the search for parental self-effective solutions is a key factor in the management of the pandemic, especially in the second or even the third wave, in terms of mental health and flexible resistance and recovery! [11,12].

\section{Limitations of the Study}

Among the limitations of the study, significant gender difference and over-representation of women in the sample should be mentioned. It is worthwhile to work with a sample of equal gender distribution in a subsequent study.

\section{Acknowledgments}

Our research was funded by the research project of the Károli Gáspár Reformed University, entitled: Investigation of family and individual protective and vulnerability factors in childhood and adolescence, the leader of the research is Dr. Rita F. Földi.

\section{Bibliography}

1. Gy Kiss E., et al. "Resilience and protective factors of personality". Psychology and Health 27.1 (2012): 222.

2. Olsson CA., et al. "Adolescent resilience: a concept analysis". Journal of Adolescence 26 (2003): 1-11.

3. Masten AS. "Ordinary magic. Resilience processes in development". American Psychologist 56 (2001): 227-238.

4. Sutcliffe KM and Vogus TJ. “Organizing for resilience”. In: Cameron KS, Dutton JE, Quinn RE, editions. Positive organizational scholarship: foundations of a new discipline. San Francisco: Berrett-Koehler (2003): 94-110.

5. Connor KM and Davidson JRT. "Development of a new resilience scale: The Connor-Davidson Resilience Scale (CD-RISC)". Depression and Anxiety 18.2 (2003): 76-82.

6. Cohen S and Williamson GM. "Perceived stress in a probability sample of the United States”. In Spacapan, S., Oskamp, S. (editions.): The Social Psychology of Health. Newbury Park, CA: Sage (1988): 3167.

7. Staudler A and Konkoly Thege B. "Az észlelt stressz kérdőív (PSS) magyar verziójának jellemzői”. Mentálhigiéné és Pszichoszomatika 7-3 (2006): 203-216.
8. Bandura A. "Self-efficacy. The exercise of control". New York: Freeman (1994).

9. Salkovskis PM., et al. "The Health Anxiety Inventory: Development and validation of scales for the measurement of health anxiety and hypochondriasis". Psychological Medicine 32.5 (2002): 843-853.

10. Köteles F., et al. "A rövidített egészségszorongás-kérdőív (SHAI) magyar verziójának kérdőíves validáslása és pszichometriai értékelése". Mentálhigiéné és Pszichoszomatika 12.3 (2011): 191-213.

11. Aspinwall LG and Tedeschi RG. "The Value of Positive Psychology for Health Psychology: Progress and Pitfalls in Examining the Relation of Positive Phenomena to Health". Annals of Behavioral Medicine 39 (2010): 4-15.

12. Járai R., et al. “Connor-Davidson Reziliencia Kérdőív 10 itemes változatának jellemzői”. Alkalmazott Pszichológia 15.1 (2015): 129-126.

\section{Assets from publication with us}

- Prompt Acknowledgement after receiving the article

- Thorough Double blinded peer review

- Rapid Publication

- Issue of Publication Certificate

- High visibility of your Published work

Website: www.actascientific.com/

Submit Article: www.actascientific.com/submission.php Email us: editor@actascientific.com

Contact us: +919182824667 